\title{
Creation of collision data base through the "bottom-up" approach
}

\author{
Alla Brom, Evgeniya Gorlacheva and Irina Omelchenko \\ Bauman Moscow State Technical University, 105005, 2-ya Baumanskaya, 5, Moscow, Russian Federation
}

\begin{abstract}
The present epoch of knowledge economy, research and innovation poses unpredictable challenges for high-tech enterprises in aerospace industry. Knowledge and technology have mostly become the key source of creating competitive advantage. However production of successful aerospace products and service is impossible without collisions. The aim of the paper is to elaborate a bottom-up approach that allows reducing collisions by setting up a database of collisions (CDB) that occurs in the life cycle process. The introduced definition of "collision" determines any breach in the implementation process, leading to a deviation in product quality. The classification of collision types is given and the stages of collision management system in aerospace enterprises are described. By means of Risk Priority Numbers (RPN) method the authors have proposed to evaluate the significance of probable production collisions. According to conclusions of the analysis, collision database allows to accumulate, formalize and store invaluable experience of skilled practitioners, especially in unique production process. Other research outcome deals with the understanding that collision database allows detecting business processes where collision occurrence is not always obvious.
\end{abstract}

\section{Introduction}

The production of rocket and space equipment assumes a large variety of industrial processes and manufacturing operations, which are characterized by their specificity: a high level of workability, a single production, high risks (financial, economic, environmental, etc.), high level of responsibility. Reliability of aerospace technology ensures due to quality engineering and manufacturing processes.

Moreover the Russian aerospace enterprises are continuously updated technological support: there are additional options, progressive design decisions, etc. In aerospace engineering and manufacturing the enforcement requirement is considered to be the continuity and knowledge transfer. The problem of continuity is achieved through the creation of a knowledge management system (KMS) in the aerospace company.

The creation of the KMS from scratch is quite costly because these costs will be recouped over a long period of time. However, space services are now very much in demand. The intensity of the space launches is increasing every year. Table 1 presents data of Russian space launches from 2010 to 2016 [1].

Table 1. Total amount of space launches (2010-2016)

\begin{tabular}{|l|r|r|r|r|r|r|r|}
\hline Year & 2010 & 2011 & 2012 & 2013 & 2014 & 2015 & 2016 \\
\hline $\begin{array}{l}\text { Total amount } \\
\text { of launches }\end{array}$ & 23 & 24 & 26 & 27 & 26 & 17 & 0 \\
\hline
\end{tabular}

The presented data suggest that the production of the satellite can be regarded as mass production. The presence of failed launches demonstrates the need for recording, collecting and processing errors, so called collisions. Reaction velocity to a collision occurred must be sufficiently high so that all admitted ones can be resolved immediately, i.e. in the manufacture of the next product.

\section{Main part}

The paper offers a pragmatic and cost saving approach to the practical realization of the collision data base creation. The proposed approach can be used as small and medium enterprises involved in aerospace projects and large-scale enterprises as well, through existing corporate information systems.

One more accepted perspective in $\mathrm{KM}$ area is knowledge influence to innovation growth. This perspective is extremely important in the high $R \& D$ intensity sectors which require radically new innovation approaches.

Knowledge acquisition can influence the $\mathrm{R} \& \mathrm{D}$ performance and it's capability to convert resources into innovative products best explains differences in enterprises' innovation performance [2]. Although the above mentioned perspectives are thoroughly elaborated there are many vague areas in KM. One of them is the warehousing and registering collisions in production process based on bottom-up approach.

Even typical and well organized production process could face unpredictable risks and obstacles. Hence the growing interest in high-tech enterprises in recent years associated with the creation of knowledge management system that would have solved the global problem of 
information formalization. But the process of implementing KMS for high-tech enterprises is rather complicated due to a number of factors:

- Corporate information system (CIS) that brings together developers, designers and production staff on a single platform are rather expensive.

- Creating internal portals that facilitate internal information exchange do not guarantee the quality of products.

- Particular characteristics in processes of unique production creates certain difficulties in the allocation and description of typical algorithms for design, engineering and production.

- There is an acute problem of the experience transfer (young workers lack the intuitive and practical experience, lack of mentoring, etc.), so that once there is a problem of formalization of experience and intuition.

Professional experience and intuition usually appear with the job age. Thus one could pose a question what the professional experience is? Our opinion is that this is the knowledge of previous errors, failures, collisions and consequences to which they lead. In these terms skilled practitioners are more competitive than the novices (inexperienced employees). So any high-tech enterprise faces a problem how to transfer knowledge from experienced professionals to younger employees? In order to find out a solution of experience and intuition transfer, a concept of collision has been introduced.

Collision is considered as any breach of production process, leading to a deviation in product quality (performance/ non-compliance of required output parameters, etc.).

We discover a collision when aerospace system or its elements:

- doesn't (don't) function at all;

- doesn't (don't) function in a definite period of time;

- functions (function) in not a proper way;

- functions (function) not in full.

The cost of making changes to the project, on average, is hundreds of times less than the cost of making changes to the finished product. Early detection and prevention of collisions at their occurrence place lead to significant cost savings for the enterprise as a whole.

Creation of collision data base (CDB) designed for such conditions will allow formalizing intuitive decisions, both the correct and incorrect, and their consequences, and also warehousing professional experience of employees and preventing failures in production process (fig.1).

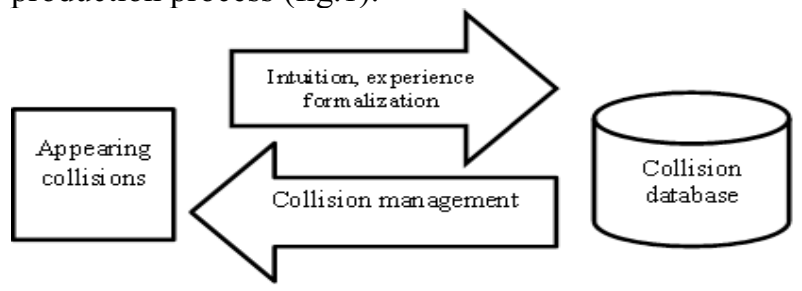

Figure 1. Collision database creation
In other words, if the aerospace enterprise hasn't opportunity to create a global knowledge management system that integrates information, experience and intuition (a "top-down" approach), it could accumulate and formalize experience in collisions and their solutions (a "bottom-up" approach).

The "bottom-up" approach allows creating and disseminating knowledge at the operational level, and only after the successful implementation of innovative proposals one can generalize the results to the enterprise level. The proposed approach also takes into account those accumulated production of knowledge held by more experienced employees (fig. 2).

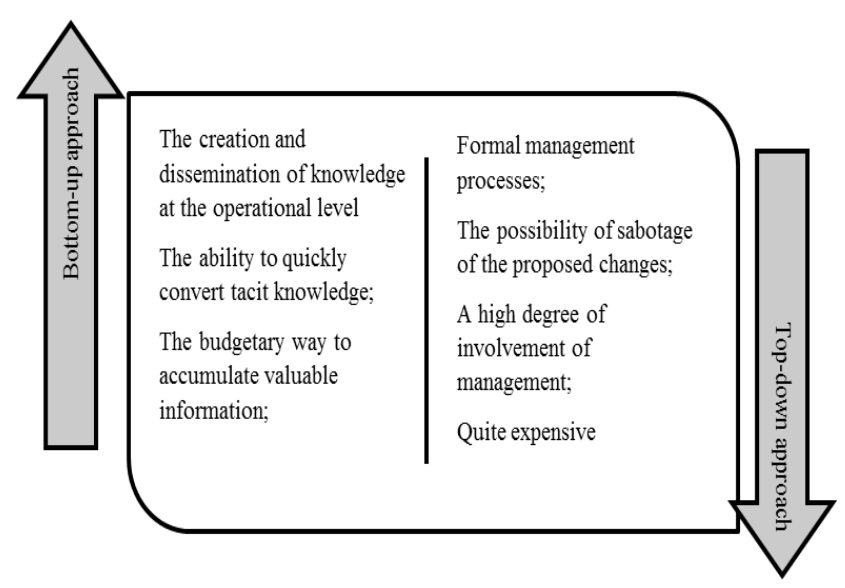

Figure 2. Main characteristics of two approaches

One of the key advantages of the "bottom-up" approach is the timely detection and prevention of production errors that occur due to the lack of sufficient professional experience. Throughout the product lifecycle, from design to the finished product, there is a lot of different changes that have a different nature arise, and may adversely affect the quality of the product.

The first step in creating CDB will systematize all possible collision types and their place of occurrence (Table 2).

Table 2. Classification of collision types

\begin{tabular}{|c|c|}
\hline Collision types & Probable examples \\
\hline Design collisions & $\begin{array}{l}\checkmark \\
\text { design documentation; } \\
\checkmark \quad \text { Errors in the selection } \\
\text { of dimensions and permissible } \\
\text { variations; } \\
\checkmark \quad \text { Errors in the selection } \\
\text { of materials for the } \\
\text { construction, by replacing } \\
\text { materials }\end{array}$ \\
\hline $\begin{array}{l}\text { Technological } \\
\text { collisions }\end{array}$ & $\begin{array}{l}\checkmark \\
\text { Errors to comply with } \\
\text { the requirements of the design } \\
\text { process and management } \\
\text { technical documentation; } \\
\checkmark \quad \text { Technological } \\
\text { documentation, allowing } \\
\text { incorrect assembly of products; } \\
\checkmark \quad \text { Errors related to the } \\
\text { selection of equipment; }\end{array}$ \\
\hline
\end{tabular}




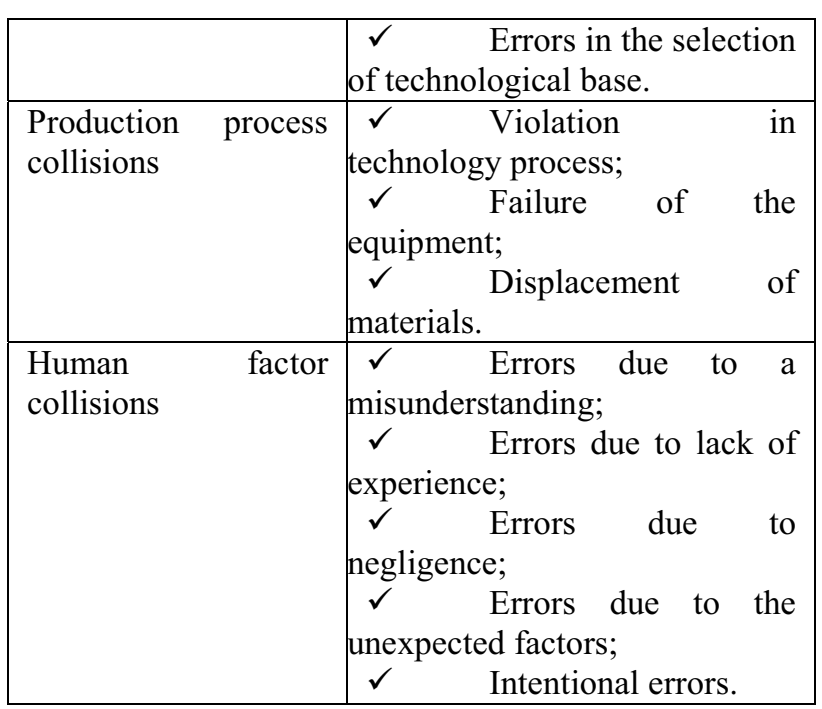

Management of CDB is a permanent process that undergoes step by step three stages: warning, monitoring and cessation (fig.3).

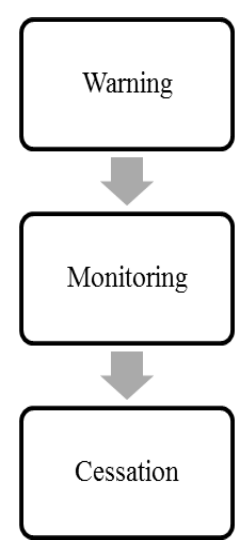

Figure 3. Management of CDB

Warning is a method by which the product could not be manufactured or assembled incorrectly, a system gives a visual or audible message to the operator to indicate potential danger.

Monitoring is a method of conformity assessment by observation and judgment accompanied by corresponding measurements, testing or calibration.

Cessation is a method that suspends production process intentionally by means of warning horns or alerting services. The main source for $\mathrm{CDB}$ is the expertise in form of survey and interviews that allow registering all negative failures.

\section{Method}

Collisions could be considered in two aspects:

- qualitative one, that consists of search and identification of collision causes and their effects, that have negative impact to consumer of aerospace technique;

- quantitative one, that implies the risk evaluation of probable collision. The objective of this evaluation is the identification and priority of potential collisions. This measure allows us to estimate the order of importance of collisions in descending order, to facilitate research and development activities in order of priority, which subsequently eliminate the causes of collisions.

In order to define the importance of appearing collisions in LC manufacturing product one can use RPN method [3].

There are three types of RPN method determined by analysis of an object (fig.4).

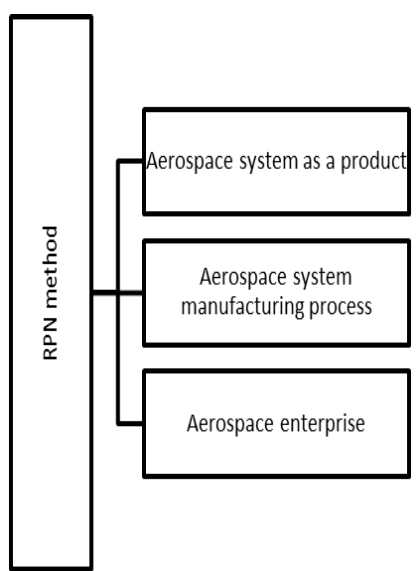

Figure 4. Types of RPN method

The first type is the analysis of an aerospace system directly (as a product). The main objective is the determination of collisions in main functions of a system.

The main aims of analysis and calculation of this type:

- Determination of main reliability parameters of an aerospace system;

- $\quad$ Specification of all manufacturing and exploitation restrictions of an aerospace system;

- Determination of critical safety parameters of an aerospace system;

- $\quad$ Taking decisions about changes in design process phase;

- $\quad$ Taking into consideration of manufacturing phases, assembly phases, repairing and transportation.

In order to document all results the authors have elaborated the spreadsheet template (table 3).

Table 3. Spreadsheet template

\begin{tabular}{|c|c|c|c|}
\hline $\begin{array}{c}\text { Collision } \\
\text { type }\end{array}$ & $\begin{array}{c}\text { Effect to } \\
\text { an } \\
\text { aerospace } \\
\text { system }\end{array}$ & $\begin{array}{c}\text { Possible } \\
\text { causes of } \\
\text { collisions }\end{array}$ & Monitoring \\
\hline & & & \\
\hline
\end{tabular}

The second type of RPN method is the analysis of an aerospace system manufacturing process. It aims to identify collisions in production processes, assembly, installation and maintenance of the product - how process can affect the parameters of the product, their deviations that do not meet certain requirements, possible causes and consequences of the result, as well as warning means to identify and eliminate such collisions.

The main aims of analysis and calculation of this type:

- match critical product characteristics and parameters of the production processes;

- make changes in the structure of production processes and their optimization;

- identify processes shortcomings;

- $\quad$ propose changes in the product concept; 
- $\quad$ identify warning means;

- $\quad$ select and follow a plan of action.

The example of a process analysis is given in the table 4 .

Table 4. Example of process analysis

\begin{tabular}{|c|c|c|c|}
\hline $\begin{array}{c}\text { Collisio } \\
\mathrm{n} \text { type }\end{array}$ & $\begin{array}{c}\text { Effect to a } \\
\text { manufacturin } \\
\text { g process }\end{array}$ & $\begin{array}{c}\text { Possible } \\
\text { causes of } \\
\text { collisions }\end{array}$ & $\begin{array}{c}\text { Monitoring } \\
\text { plan }\end{array}$ \\
\hline $\begin{array}{c}\text { Collisio } \\
\mathrm{n} \text { in } \\
\text { assembl } \\
\text { Impossibility } \\
\text { of launch }\end{array}$ & $\begin{array}{c}\text { Design } \\
\text { causes; } \\
\text { Equipme }\end{array}$ & $\begin{array}{c}\text { Monitoring at } \\
\text { all } \\
\text { manufacturing } \\
\text { phases }\end{array}$ \\
\hline
\end{tabular}

The third type of RPN method is used for various process control levels of an aerospace enterprise, administration and production: the first level integrates administrative system, information system, human resources management, the last level includes the organization of the basic working units.
While using the Risk Priority Number (RPN) method to assess risk of consequences, the analysis team must:

- Determine the type of collision;

- Rate the severity (S), the likelihood of occurrence (O), and the likelihood of prior detection (D) for each collision

- Calculate the RPN by multiplying three ratings: $\mathrm{RPN}=$ Severity $\mathrm{x}$ Occurrence $\mathrm{x}$ Detection

The parameters $\mathrm{S}, \mathrm{O}, \mathrm{D}$ range from 1 to 10 . Thus, the maximum value of 1,000 RPN. The classification is carried out for the serious consequences of each type of collision shown in table. 5 .

The RPN method based on expert evaluations shows that human factor collisions may have more negative impact than technological collisions.

The next step in CDB management identifies all the potential collisions in order to assess the more critical ones. As discussed, a collision can be considered as: (i) the real lack of capacity to perform a certain action, or (ii) the presumed/perceived inability to perform it.

\section{Analysis}

Table 5. Short Example of RPN method application in collision management

\begin{tabular}{|c|c|c|c|c|c|c|c|c|}
\hline \multicolumn{3}{|c|}{ Severity Ranking Index } & \multicolumn{3}{|c|}{ Occurrence Ranking Index } & \multicolumn{3}{|c|}{ Detection Ranking Index } \\
\hline Rank & Criteria & & $\begin{array}{l}\mathrm{R} \\
\text { ank }\end{array}$ & Crit & & $\begin{array}{l}\mathrm{R} \\
\text { ank }\end{array}$ & \multicolumn{2}{|c|}{ Criteria } \\
\hline 1 & $\begin{array}{l}\text { Undetect } \\
\text { system }\end{array}$ & able effect on & 1 & $\begin{array}{r}\text { Ren } \\
\text { collisio }\end{array}$ & te chance for & 1 & \multicolumn{2}{|c|}{$\begin{array}{c}\text { Almost certain } \\
\text { detection of collision }\end{array}$} \\
\hline $\begin{array}{r}2 \\
3 \\
\end{array}$ & $\begin{array}{l}\text { Low } \mathrm{S} \\
\text { Insignificant } \\
\text { functioning }\end{array}$ & $\begin{array}{l}\text { everity impact. } \\
\text { violation of }\end{array}$ & $\begin{array}{l}2 \\
3\end{array}$ & $\begin{array}{l}\text { Low } \\
\text { based o } \\
\text { with lor }\end{array}$ & $\begin{array}{l}\text { collision rate } \\
\text { previous designs } \\
\text { collisions }\end{array}$ & 3 & \multicolumn{2}{|c|}{$\begin{array}{l}\text { Very high likelihood } \\
\text { of detecting collision } \\
\text { High likelihood of } \\
\text { detecting collision }\end{array}$} \\
\hline$\frac{4}{5}+$ & $\begin{array}{l}\text { Medium } \\
\text { tasks can } \\
\text { Production } 1 \\
\text { ceased. Th } \\
\text { any tasks } \\
\text { after repairir }\end{array}$ & $\begin{array}{l}\text { severity. Several } \\
\text { 't be done. } \\
\text { orocess has to be } \\
\text { fulfillment of } \\
\text { is possible only } \\
\text { ig. }\end{array}$ & $\begin{array}{l}4 \\
5 \\
6\end{array}$ & $\begin{array}{l}\text { Mec } \\
\text { based } \\
\text { with ha } \\
\text { collisio } \\
\text { proport }\end{array}$ & $\begin{array}{l}\text { um collision rate } \\
\text { similar designs } \\
\text { some occasional } \\
\text { but not in major } \\
\text { ns }\end{array}$ & 6 & \multicolumn{2}{|c|}{$\begin{array}{l}\text { Moderately high } \\
\text { likelihood of detecting } \\
\text { collision } \\
\text { Moderate likelihood } \\
\text { of detecting collision } \\
\text { Low likelihood of } \\
\text { detecting collision }\end{array}$} \\
\hline $\begin{array}{l}7 \\
8\end{array}$ & $\begin{array}{l}\text { Heavy } \\
\text { functioning. } \\
\text { can't be ful } \\
\text { of complex } \\
\text { recovery }\end{array}$ & 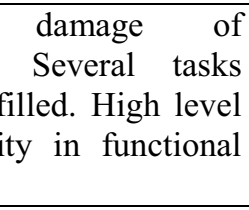 & $\frac{7}{8}$ & $\begin{array}{l}\text { Hig } \\
\text { based } \\
\text { which } \\
\text { troubles }\end{array}$ & $\begin{array}{lr}\text { collision rates } \\
\text { similar designs } \\
\text { have } \\
\text { me been }\end{array}$ & 8 & \multicolumn{2}{|c|}{$\begin{array}{l}\text { Very low likelihood } \\
\text { of detecting collision } \\
\text { Remote likelihood of } \\
\text { detecting collision }\end{array}$} \\
\hline $\begin{array}{l}9 \\
10\end{array}$ & $\begin{array}{l}\text { Very } \\
\text { inyblving } \\
\text { problem com } \\
\text { conformity }\end{array}$ & $\begin{array}{l}\text { severe problem } \\
\text { potential } \\
\text { r majety } \\
\end{array}$ & $\begin{array}{l}9 \\
1\end{array}$ & $\begin{array}{l}\text { Ver } \\
\text { rates a } \\
\text { will be }\end{array}$ & $\begin{array}{l}\text { high collision } \\
d \text { the collisions } \\
\text { lajor occurrence }\end{array}$ & $6^{9}$ & \multicolumn{2}{|c|}{\begin{tabular}{lr}
\multicolumn{1}{c}{ Very } & remote \\
likelihood of & detecting \\
collision & \\
Cannot & detect \\
collision &
\end{tabular}} \\
\hline \multicolumn{3}{|c|}{$\begin{array}{l}\text { Collision type and its } \\
\text { example }\end{array}$} & \multicolumn{2}{|c|}{$\begin{array}{l}\text { Occ Irrence } \\
\text { Index }(O)\end{array}$} & $\begin{array}{c}\text { Detection } \\
\text { Index (D) }\end{array}$ & \multicolumn{2}{|c|}{$\begin{array}{l}\text { Risk } \\
\text { Priority } \\
\text { Number } \\
\qquad(\mathbf{O}) *(\mathrm{~S}) *(\mathrm{D})\end{array}$} & $\begin{array}{l}\text { Recommend } \\
\text { ed } \quad \text { Action } \\
\text { (should } \quad \text { be } \\
\text { elaborated as } \\
\text { corporate } \\
\text { standards) } \\
\end{array}$ \\
\hline Desig & $\begin{array}{l}\text { isions } \\
\text { ect } \\
\text { tion of } \\
\text { nentation; }\end{array}$ & $1-^{4}$ & - & & 81 & 224 & & $\begin{array}{l}\quad \text { Check } \\
\text { design } \\
\text { documentation }\end{array}$ \\
\hline
\end{tabular}




\begin{tabular}{|c|c|c|c|c|c|}
\hline $\begin{array}{llr}\checkmark \text { Errors in } & \text { the } \\
\text { selection } & \text { of } \\
& \text { dimensions } & \text { and } \\
\text { permissible } & \\
\text { variations; } & \end{array}$ & & & & & \\
\hline $\begin{array}{l}\text { Technological } \\
\text { collisions } \\
\checkmark \quad \text { Errors related to } \\
\text { the selection of } \\
\checkmark \text { equipment; } \\
\checkmark \quad \text { Errors in the } \\
\text { selection of } \\
\text { technological } \\
\text { base. }\end{array}$ & 2 & 6 & 5 & 60 & $\begin{array}{l}\quad \text { Check } \\
\text { technology } \\
\text { documentation } \\
\text { \& process }\end{array}$ \\
\hline $\begin{array}{l}\text { Production process } \\
\text { collisions } \\
\checkmark \quad \text { Displacement of } \\
\quad \text { materials; } \\
\checkmark \quad \begin{array}{l}\text { Failure of the } \\
\text { equipment. }\end{array}\end{array}$ & 3 & 4 & 5 & 60 & $\begin{array}{l}\quad \text { Check } \\
\text { production } \\
\text { process }\end{array}$ \\
\hline $\begin{array}{l}\text { Human factor } \\
\text { collisions } \\
\checkmark \quad \text { Errors due to lack } \\
\quad \text { of experience; } \\
\checkmark \quad \begin{array}{l}\text { Errors due to } \\
\text { negligence; }\end{array} \\
\end{array}$ & 9 & 7 & 7 & 441 & $\begin{array}{l}\quad \text { Establish } \\
\text { motivation } \\
\text { factors, } \\
\text { implement } \\
\text { coaching } \\
\text { process }\end{array}$ \\
\hline
\end{tabular}

\section{Conclusion}

The application of RPN method to CDB management looks promising. It is important to open a dialogue between skilled professionals and younger workers. Sharing a common language is extremely powerful in order to establish shared visions of the future. Second, we suggest that RPN analysis is applied systematically in all cases where there are collisions in lifecycle process.

\section{References}

1. Statistics data from Federal space agency // http://www.federalspace.ru/launch/2010

2. B. Urgal et al., Knowledge resources and innovation performance: the mediation of innovation capability moderated by management commitment. Technology Analysis \& Strategic Management, 25, (2013).

3. Barringer P. Failure mode and effects analysis, // www.barringer1.com/nov07prb.htm (2009) 